\title{
Isolation of a wide range of minerals from a thermally treated plant: Equisetum arvense, a Mare's tale
}

\author{
Anna Sola-Rabada $^{1} \cdot$ Julia Rinck $^{2,3} \cdot$ David J. Belton $^{1} \cdot$ Annie K. Powell $^{2} \cdot$ \\ Carole C. Perry ${ }^{1}$
}

Received: 4 November 2015 / Accepted: 8 December 2015 / Published online: 13 January 2016

(C) The Author(s) 2016. This article is published with open access at Springerlink.com

\begin{abstract}
Silica is the second most abundant biomineral being exceeded in nature only by biogenic $\mathrm{CaCO}_{3}$. Many land plants (such as rice, cereals, cucumber, etc.) deposit silica in significant amounts to reinforce their tissues and as a systematic response to pathogen attack. One of the most ancient species of living vascular plants, Equisetum arvense is also able to take up and accumulate silica in all parts of the plant. Numerous methods have been developed for elimination of the organic material and/or metal ions present in plant material to isolate biogenic silica. However, depending on the chemical and/or physical treatment applied to branch or stem from Equisetum arvense; other mineral forms such glass-type materials (i.e. $\mathrm{CaSiO}_{3}$ ), salts (i.e. $\mathrm{KCl}$ ) or luminescent materials can also be isolated from the plant material. In the current contribution, we show the chemical and/or thermal routes that lead to the
\end{abstract}

This article is a contribution to the current volume in memory of Professor R. J. P. Williams, FRS, the DPhil advisor of CCP and arose from research initiated whilst CCP was Gast professor at the Institute of Inorganic Chemistry, Karlsruhe Institute for Technology (KIT), Germany in 2012.

Electronic supplementary material The online version of this article (doi:10.1007/s00775-015-1320-0) contains supplementary material, which is available to authorized users.

Carole C. Perry

carole.perry@ntu.ac.uk

1 Interdisciplinary Biomedical Research Centre, Nottingham Trent University, Clifton Lane, Nottingham NG11 8NS, UK

2 Karlsruhe Institute of Technology, Institute of Inorganic Chemistry, Engesserstrasse 15, 76131 Karlsruhe, Germany

3 Karlsruhe Institute of Technology DFG-Center for Functional Nanostructures (CFN), Wolfgang-Gaede-Straße 1a,

76131 Karlsruhe, Germany formation of a number of different mineral types in addition to biogenic silica.

Keywords Silica $\cdot$ Equisetum arvense $\cdot$ Wollastonite . Calcium sulphide $\cdot$ Vitrification

\section{Introduction}

Silica is one of the most common materials in nature and is the second most common biogenic mineral after carbonates [1], and it is deposited in living organisms, including animals, plants and diatoms [2]. Horsetail (Equisteum spp.) is classified as one of the most ancient species of living vascular plants [3]. A remarkable characteristic of Equisetum species is their ability to take up and accumulate silica in their tissues giving the epidermis a rough texture [4]. Back in the 1980s, Williams and co-workers were one of the first groups to characterize the nature of silica in biological systems by using transmission electron microscopy, FTIR and NMR spectroscopy [5]. This natural silica, often referred to as biogenic silica, is present in the form of amorphous silica $[5,6]$ and for some plants seems to be an essential mineral for growth [7]. The ability of plants to produce biogenic silica with a wide range of morphologies under mild physiological conditions is of great interest to scientists (and industry); as it gives the material exceptional properties, such as ordered hierarchical porous structures applicable for catalysis [8], biosensing [9] and biomedical applications [9]. Further, plants and other biological organisms (i.e. sponges or diatoms) produce silica in amounts of gigatons per annum, whereas industrial processes only produce mere megatons. Biogenic silica in plants is present together with the organic matrix, including polymers (i.e. cellulose), proteins, other carbohydrates, lipids, metal ions (such 

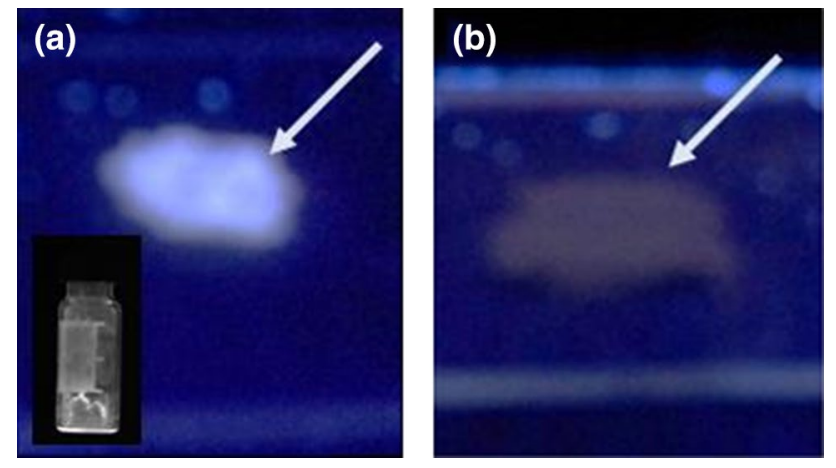

Fig. 1 Samples (from the branches of Equisetum arvense) irradiated with blue light are a acetone treated/incomplete digestion/heat treated under $\mathrm{H}_{2} / \mathrm{Ar}$ and $\mathbf{b}$ non-acetone treated/incomplete digestion/heat treated under $\mathrm{H}_{2} / \mathrm{Ar}$

as $\mathrm{Ca}, \mathrm{K}, \mathrm{S}, \mathrm{Cl}, \mathrm{Na}, \mathrm{Al}$ and $\mathrm{P}$ ), and phenolic compounds, which also play an important role in the hierarchical structures of biosilica [10]. The distribution and amount of silicon and other metal ions vary between individual plant families [11] and, within the plant, depending on the anatomical region studied [6]. For example, macrohairs from the lemma of the grass Phalaris canariensis L., showed a higher deposition of silicon, as silica throughout the macrohair for the mature stages of the plant; whereas for early stages (immature plant), silicon, as silica was mainly deposited at the tip of the microhair [6]. In addition, the silica formed in these plant hairs was remarkably free of metal ions [6]. In Equisetum arvense, silica was found to be located within the secondary cell wall providing mechanical strength and rigidity to the plant [4].
Biogenic amorphous silica from plants has been extracted by a number of different methods [12-17]. However, during the extraction procedure, there are also reports of the presence of crystalline silica forms, such as $\alpha$-quartz, after removal of the cell wall matrix by ashing [18, 19]. Besides this, the presence of either other minerals (i.e. $\mathrm{Ca}^{2+}$ mineral types) [20] or metal ions in plant materials subjected to chemical and/or physical treatments, can result in the formation of new materials. As such, it is important to know both the composition of the native material and the effect of specific treatment(s) on the composition of the materials that may arise.

The present study arose following two observations: (1) thermal treatment of samples of Equisetum arvense, using a conventional ashing approach yielded X-ray diffraction patterns that contained numerous peaks that were not related to silica and (2) following thermal treatment, samples occasionally showed luminescence behavior in the presence of UV light (Fig. 1). The study arose out of a need to understand where the luminescence comes from and was extended to include the effect of processing conditions on minerals formed from different parts of a plant, in this case the branches and stems of Equisetum arvense.

\section{Materials and methods}

Stems and branches of Equisetum arvense were collected from the campus of Karlsruhe Institute of Technology, in Germany in May/June 2012. Fresh samples were dried immediately then stored at room temperature in the dark. A number of different treatments (Scheme 1) were performed

Scheme 1 Methodology followed for the treatment of Equisetum arvense plant material

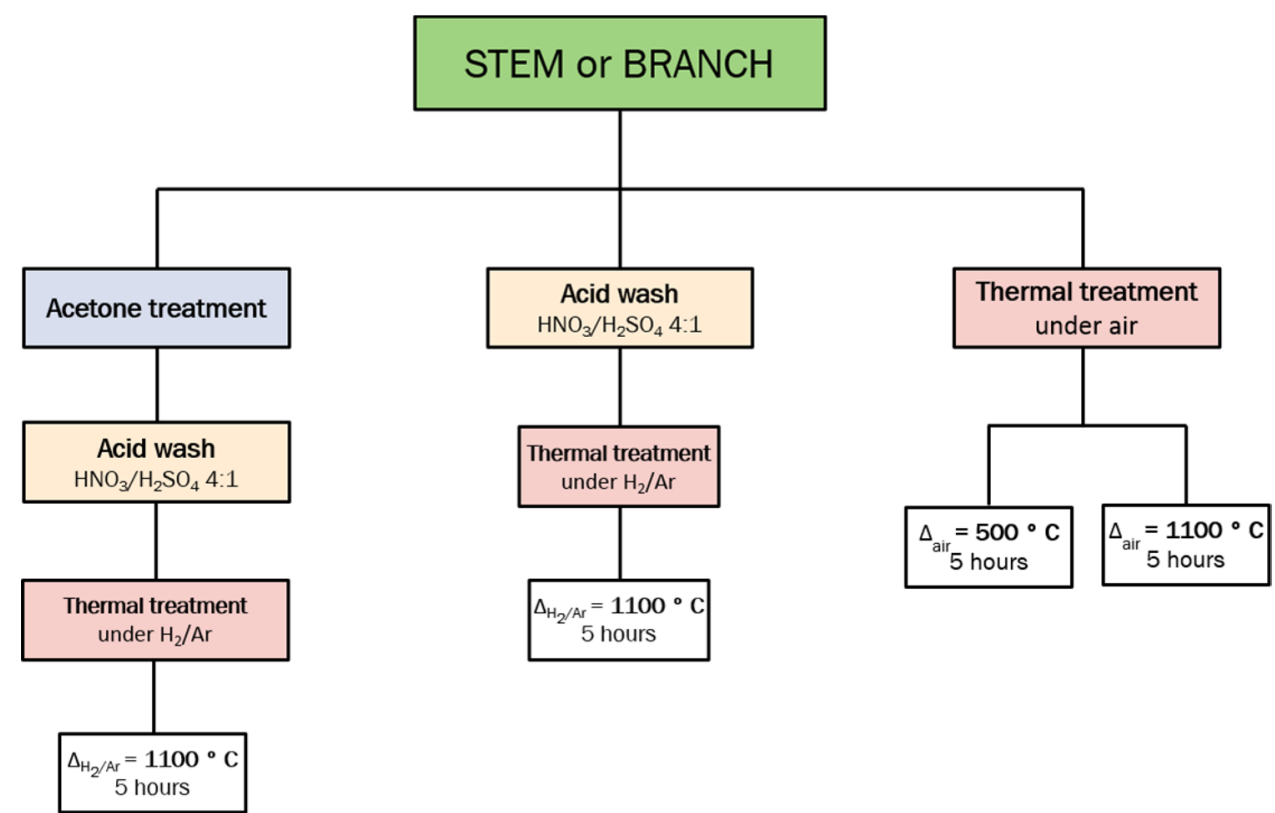


to study the elemental composition, characteristics and properties of the materials generated. Plants were separated into stems and branches and dried in an oven at $50{ }^{\circ} \mathrm{C}$ prior to acid digestion in concentrated $\mathrm{HNO}_{3} / \mathrm{H}_{2} \mathrm{SO}_{4}$ (4:1). To avoid acid burning, the plant material was first covered with nitric acid and the sulphuric acid then added carefully into the system. The mixture was stirred and left in a fume hood until a fine white precipitate was obtained and the release of oxides of nitrogen had stopped, usually around $48 \mathrm{~h}$. Precipitates were isolated and washed with copious amounts of deionized water until the $\mathrm{pH}$ value of the water was ca. 5. The samples were then lyophilized before being heat-treated either under $\mathrm{H}_{2} / \mathrm{Ar}$ or air at $1100{ }^{\circ} \mathrm{C}$ for $5 \mathrm{~h}$ with a heating rate of $10{ }^{\circ} \mathrm{C} / \mathrm{min}$ up to the maximum set temperature. Another set of samples was prepared as above but, in addition, a treatment with acetone to remove chlorophyll was performed prior to the acid digest. After treatment, the acetone solution was decanted and any remaining solvent evaporated with the aid of a rotary evaporator. Finally, a comparison study was carried out where the native plant material was only heat treated (no acid digest) in air at temperatures of 500 and $1100{ }^{\circ} \mathrm{C}$ for $5 \mathrm{~h}$ with a heating rate of $10^{\circ} \mathrm{C} / \mathrm{min}$ up to the maximum temperature.

The morphology of the samples was determined by SEM (JEOL JSM-840A, $20 \mathrm{kV}$ ). Samples were attached to aluminum stubs using double-sided carbon adhesive tape and carbon coated (Edwards, sputter coater S150B). The crystallinity of the precipitates obtained was characterized using XRD (PANalytical X'Pert PRO, $\mathrm{Cu} \mathrm{K} \alpha$ radiation with wavelength of $1.54056 \AA$ ). Ground samples (if necessary) were packed into an aluminum sample holder and scanned from $5^{\circ}$ to $80^{\circ}$ of $2 \theta$ at an accelerating voltage of $45 \mathrm{kV}, 40 \mathrm{~mA}$ filament current, using a scan speed of $0.02^{\circ} \mathrm{s}^{-1}$ at room temperature. Diffraction patterns were analyzed using X'Pert-HighScore Plus (Version 2.0a) program for diffractogram manipulation, background determination and peak identification. For small amounts of sample, a polypropylene (PP) mask was fitted into the aluminum holder. ATR (Perkin Elmer Spectrum 100 FTIR Spectrometer with Diamond/KRS-5 crystal) was used to detect the functional groups present in the samples. Spectra were averaged from 32 scans at $4 \mathrm{~cm}^{-1}$ resolution with air as background. The organic content in the samples was determined by TGA (Mettler Toledo TGA/SDTA $851^{\mathrm{e}}$ ). Samples were heated at $10^{\circ} \mathrm{min}^{-1}$ from 30 to $900{ }^{\circ} \mathrm{C}$ in air to ensure complete combustion of all organic material. The concentration of silicon $(\mathrm{Si})$, calcium $(\mathrm{Ca})$, potassium $(\mathrm{K})$ and sulphur ( $\mathrm{S}$ ) in the samples was determined by using ICP-OES (Optima 2100DV). Samples $(50 \mathrm{mg}$ ) were fused into a Ni crucible with solid ground $\mathrm{NaOH}(5 \mathrm{~g})$ at $400{ }^{\circ} \mathrm{C}$ during 15 min using a temperature ramp of $10^{\circ} \mathrm{min}^{-1}$. Collected samples were dissolved in distilled water and after $1 \mathrm{~h}$ acidified with concentrated nitric acid $\left(\mathrm{HNO}_{3}\right)$. Final samples $\left(1000 \mathrm{ppm}\right.$ in $\left.10 \% \mathrm{HNO}_{3}\right)$ were filtered with a $0.45 \mu \mathrm{m}$ disc filter prior to analysis. Standard solutions for each element were prepared from $1000 \mathrm{ppm}$ stock solutions purchased from BDH Laboratory Supplies. The amount of each was determined by comparison with standards of known concentrations $(0-100 \mathrm{ppm}$, correlation coefficient of 0.999) using a wavelength of 251.6 for $\mathrm{Si}, 317.9$ for $\mathrm{Ca}$, 766.5 for K and 182.0 for S. For measurement of luminescence, samples were irradiated with blue light $(302 \mathrm{~nm})$ and luminescence measured visually.

\section{Results and discussion}

\section{Composition of the native plant material}

Native Equisetum arvense was studied to identify the elemental composition and the minerals that could be present in the samples (branch and stem). SEM analysis (Fig. 2) showed, predominantly, two types of structures: multi-laminate layers (Fig. 2a) and spotted surfaces (Fig. 2b) which generally contained a stomatal shape (Fig. 2c), similar to structures identified previously [4].

EDX analysis (Fig. 3) showed the presence of a wide range of elements in the plant material. The atomic \% of $\mathrm{Si}$ was found to be higher in the stem compared to the branch. These results were in accordance with the data obtained by ICP-OES where $\%$ of $\mathrm{Si}$ was $2.4 \pm 0.1 \%$ in branches and $3.8 \pm 0.6 \%$ in stems. Other elements, such as calcium $(\mathrm{Ca})$, potassium $(\mathrm{K})$, sulphur $(\mathrm{S})$, sodium $(\mathrm{Na})$, magnesium $(\mathrm{Mg})$, chlorine $(\mathrm{Cl})$ and phosphorus $(\mathrm{P})$ were also detected in the samples (Fig. 3). Ca was more likely to be found in branches $(2.6 \pm 0.2 \%)$ than in stems $(1.1 \pm 0.2 \%)$; together with $\mathrm{Mg}, \mathrm{Cl}, \mathrm{S}$ and $\mathrm{P}$ (listed in order of decreasing \%). In contrast, stems contained a higher amount of $\mathrm{K}$ compared with the branches, being $10.2 \pm 0.5 \%$ and $3.6 \pm 0.2 \%$, respectively. Equisetum spp. has been used as a decontaminant of soils (known as phytoremediation) due to its potential for metal uptake from soil [21, 22]. Thus the elemental composition may vary depending on the geographical area and the conditions (contaminated or not) of the soil. The high concentration of potassium found may be due to their growth in a potassium-rich soil. Potassium in its ionic form $\left(\mathrm{K}^{+}\right)$is an essential macronutrient in plants as it is vital for many functions such as maintenance of electrical potential gradients across the cell membranes [23] or enzyme activation [24] and its uptake in plants can vary from 1 to $10 \%$ in dry matter [25]. In contrast, the amount of silicon found in horsetail (dry matter: 2.5-4.8\%), was not influenced by the increase of silicon levels in the soil [16]. Sample mapping (Supplementary Figure 1) showed that structures with spotted surface contained mainly $\mathrm{Si}$ and $\mathrm{O}$, whereas for the multi-laminate layers a higher amount 

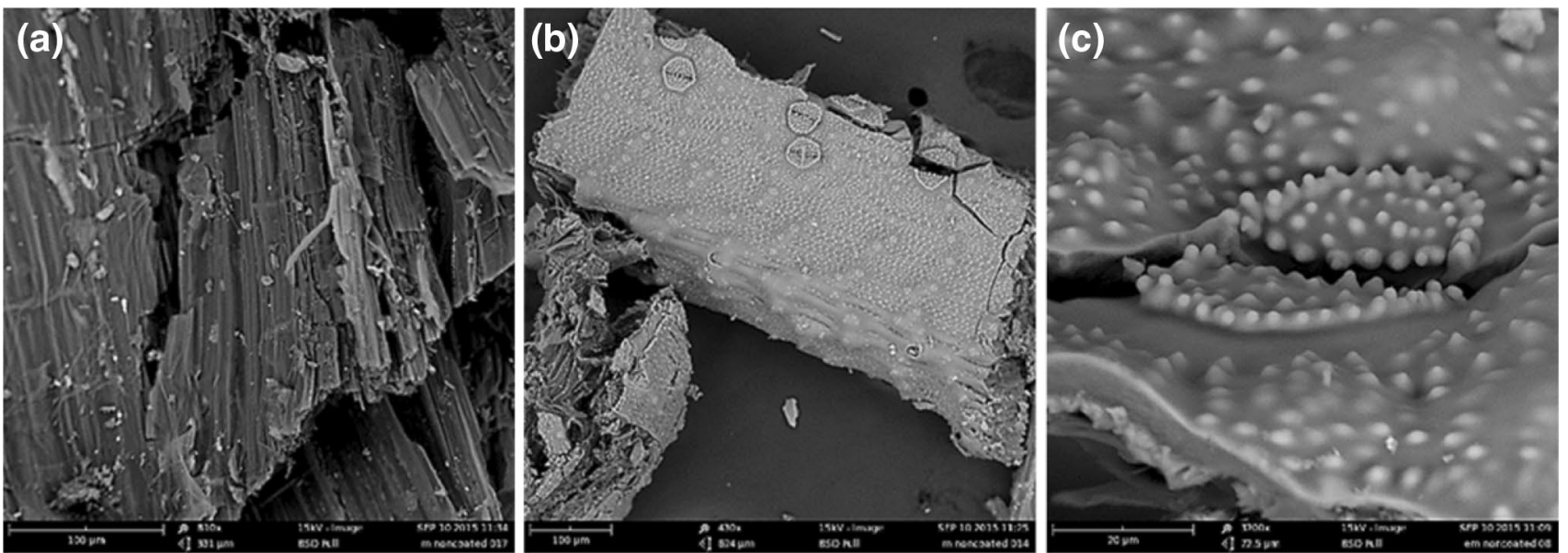

Fig. 2 SEM images of Equisetum arvense plant showing two distinct types of structure: a multi-laminate layers, b spotted surface and $\mathbf{c}$ stomata shape within the spotted surface. Scale bars are $100 \mu \mathrm{m}(\mathbf{a}, \mathbf{b})$ and $20 \mu \mathrm{m}(\mathbf{c})$

(a)

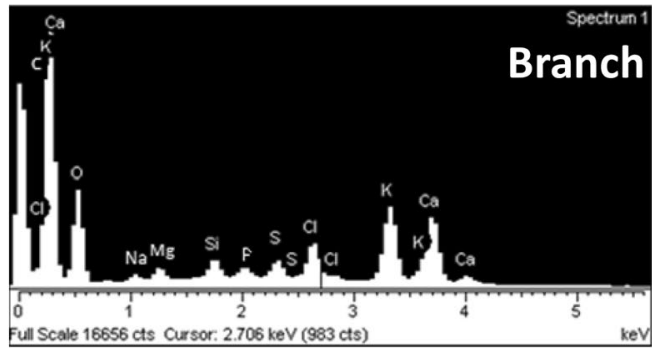

(b)

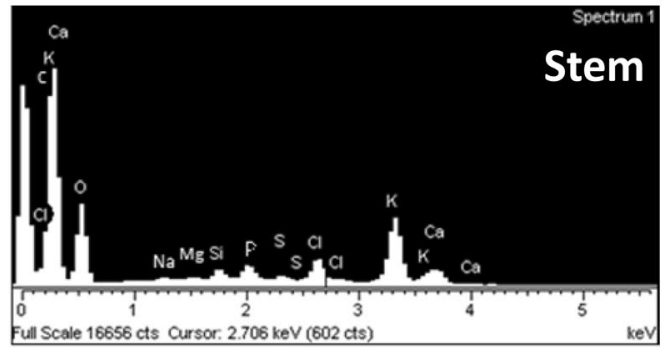

Fig. 3 EDX spectra of Equisetum arvense $\mathbf{a}$ branch and $\mathbf{b}$ stem. All elements detected in the sample are labeled

of $\mathrm{K}$ and $\mathrm{Ca}$ was detected compared to the Si levels. Other elements were also more likely to be found in the multilaminate structure. Previous studies have shown that the distribution and amount of silicon and other metal ions vary within the plant, depending on the anatomical region studied [6], being the mineralized silica more dense on the outer layer of the Equisetum arvense plant [26], which corresponds to the spotted surface shown in Fig. $2 b-c$. On the other hand, potassium can be found in the vacuole and the cytosol pools of the plant cells [27], whereas calcium is commonly found in the plant walls [28]. Note that, deposition of silica in plants has also been investigated using optical techniques by applying staining procedures based on the reactivity of silanol groups in biosilica such as methyl red, crystal violet lactone and silver amine chromate [29, 30]. And most recently, the fluorophore PDMPO has been shown to be an ideal fluorescent tracer for $\mathrm{Si}[31,32]$.

XRD analysis of the native plant samples revealed typical reflections of cellulose (Fig. 4). Cellulose can exist in many polymorphs (Cellulose I, II, III and IV with

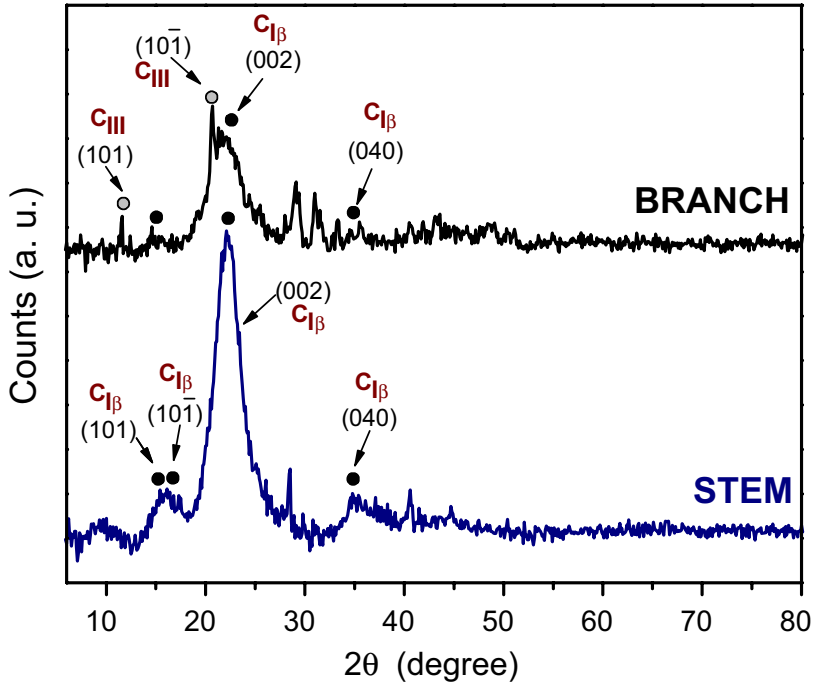

Fig. 4 XRD diffractograms from native Equisetum arvense (branch and stem). Crystallographic phases identified are: cellulose $\mathrm{I}_{\beta}$ (filled black circle) and cellulose $\mathrm{III}_{\mathrm{I}}$ (filled gray circle). Miller indices correspond to the crystal planes of cellulose $\mathrm{I}\left(\mathrm{C}_{\mathrm{I}}\right)$ and cellulose $\mathrm{III}_{\mathrm{I}}\left(\mathrm{C}_{\mathrm{III}}\right)$ 
Fig. 5 Peaks assigned from ATR spectra of native Equisetum arvense for the branches and the stems

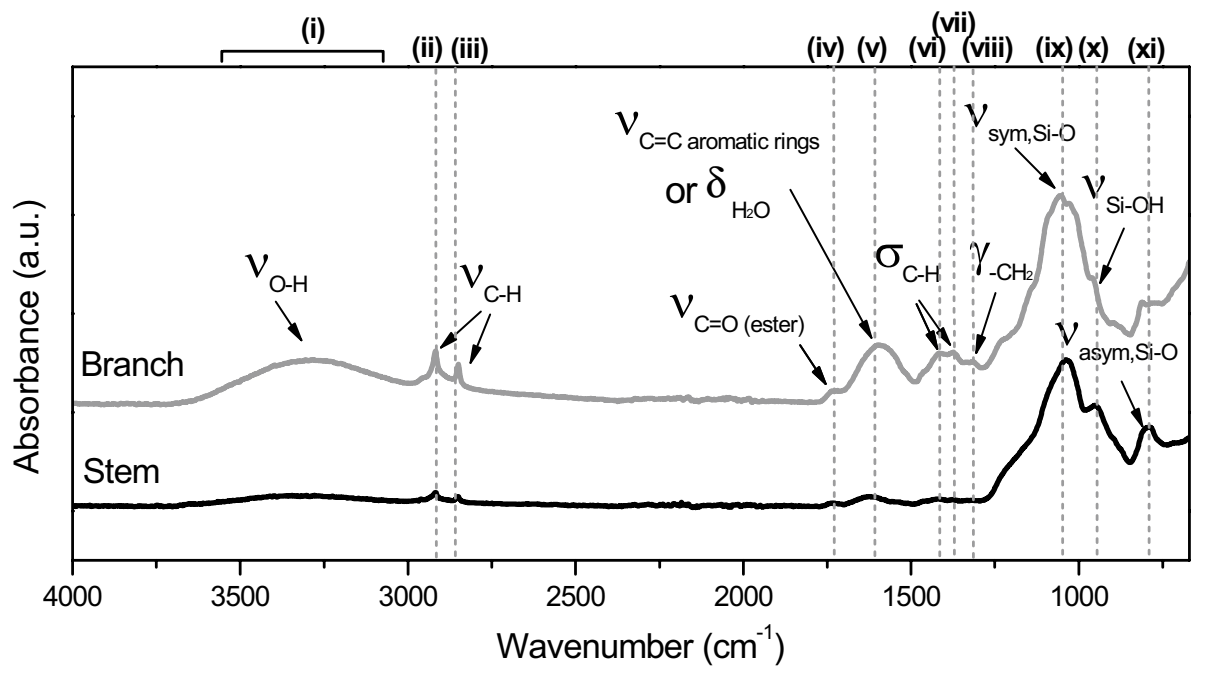

additional sub-classifications) due to the hydroxyl groups within the structure being involved either in intra- or intermolecular hydrogen bonding which results in a different arrangement of atoms throughout the structure [33]. Both samples contained cellulose $\mathrm{I}_{\beta}$ (monoclinic) with a primary peak at $2 \theta \sim 22.5^{\circ}$ corresponding to the (002) plane; and, a secondary broad peak $\left(2 \theta \sim 16.0^{\circ}\right)$ corresponding to the overlap of the (101) and (10) planes [34, 35]. The reflection at $2 \theta \sim 34.7^{\circ}$ was attributed to the (040) plane. In the branches a number of the reflections not present in the diffractogram from the stem are suggested to arise from cellulose III even though this is not commonly found in plant materials being usually generated by treating cellulose I or II in liquid ammonia [36]. The peaks at $\sim 11.6^{\circ}$ and $\sim 20.7^{\circ}$ could be attributed to typical reflections of Cellulose III $_{\mathrm{I}}$ [37]. The peak situated at lower $2 \theta$ is attributed to the (101) planes, whereas the second peak is a contribution of the (10) and the (002) planes. Due to a higher order in the cellulose III structure [38] these reflections are expected to present a sharper appearance as is observed in this sample. The other two peaks found at $\sim 29.1^{\circ}$ and $\sim 31.2^{\circ}$ in the branches are at $\sim 28.4^{\circ}$ and $\sim 40.6^{\circ}$ in the stems could not be uniquely identified. Further, amorphous silica with a characteristic XRD peak around $2 \theta \sim 22.5^{\circ}$ could not be discounted due to possible overlap with the (002) plane of cellulose $\mathrm{I}_{\beta}$ type.

ATR spectra of the samples (Fig. 5) presented a broad peak at $3600-3000 \mathrm{~cm}^{-1}$ (peak i) attributed to the $\mathrm{O}-\mathrm{H}$ stretching mode in water $\left(3500-3000 \mathrm{~cm}^{-1}\right)$ [39] and/or hydrogen bonded silanol groups (3400-3200 $\mathrm{cm}^{-1}$ ) [40]. Bands between 3000 and $2800 \mathrm{~cm}^{-1}$ can arise from vibrations involving methyl and methylene cellulose groups [41]. Thus, the peaks at $2918 / 2850 \mathrm{~cm}^{-1}$ (peaks ii and iii) and at $\sim 1415 / 1376 \mathrm{~cm}^{-1}$ (peaks vi and vii) were attributed to $\mathrm{C}-\mathrm{H}$ stretching and $\mathrm{C}-\mathrm{H}$ bending modes, respectively [39]. The peak at $1318 \mathrm{~cm}^{-1}$ (peak viii) was also assigned to alkyl groups, specifically to the $-\mathrm{CH}_{2}$ wagging mode [39]. A stronger signal from the alkyl groups was observed in the branches than in the stems. These peaks can be associated with the presence of cellulose, lignin and hemicellulose present in the plants, as well as the presence of other substance such as waxes, essential oils or resins. Some of these compounds (i.e. waxes) may also show the $\mathrm{CO}$ vibration mode, which could be indicated by the peak detected at $\sim 1740 \mathrm{~cm}^{-1}$ (peak iv) [42]. A broad peak at $\sim 1628 \mathrm{~cm}^{-1}$ (peak v) can be either associated with adsorbed water in cellulose and/or hemicellulose [41, 43] or aromatic and $\mathrm{C}=\mathrm{C}$ functional groups originating from waxes, fatty acids, fatty esters, or high molecular mass aldehydes or ketones [42]. Characteristic silica peaks at $1038 \mathrm{~cm}^{-1}$ (peak ix), $957 \mathrm{~cm}^{-1}$ (peak x) and $796 \mathrm{~cm}^{-1}$ (peak xi), corresponding to the antisymmetric $\mathrm{Si}-\mathrm{O}-\mathrm{Si}$ stretching mode, $\mathrm{Si}-\mathrm{OH}$ stretching mode and symmetric $\mathrm{Si}-\mathrm{O}-\mathrm{Si}$ stretching mode, respectively [40], were detected.

Thermal decomposition (TGA analysis) of the plant material showed a slightly bigger total \% weight loss (\%wt) for the stems than the branches, being $81.8 \pm 0.1 \%$ and $80.4 \pm 0.1 \%$, respectively. Four stages of weight loss were observed (Fig. 6). In the first stage, release of physisorbed water or volatile oils present in the native material $\left(T<120^{\circ} \mathrm{C}\right)$ occurs. In the second stage $\left(180-380{ }^{\circ} \mathrm{C}\right)$, the degradation of hemicellulose and cellulose pyrolysis gives the maximum rate of weight loss at $\sim 278{ }^{\circ} \mathrm{C}$ for the stems and $294{ }^{\circ} \mathrm{C}$ for the branches [44]. For stage three, the maximum rate of weight loss was at $\sim 477^{\circ} \mathrm{C}$ and $\sim 431^{\circ} \mathrm{C}$ in the branch and stem, respectively. Full degradation of lignin has been reported, according to Wiedemann, between 380 and $450{ }^{\circ} \mathrm{C}$ [45]; or at even higher temperatures (400-800 ${ }^{\circ} \mathrm{C}$ ), as reported by $\mathrm{Lv}$ et al.; but in all cases, the destruction of lignin occurs at a higher temperature than cellulose, due to the presence of aromatic compounds which makes lignin more thermally stable during pyrolysis 
(a)

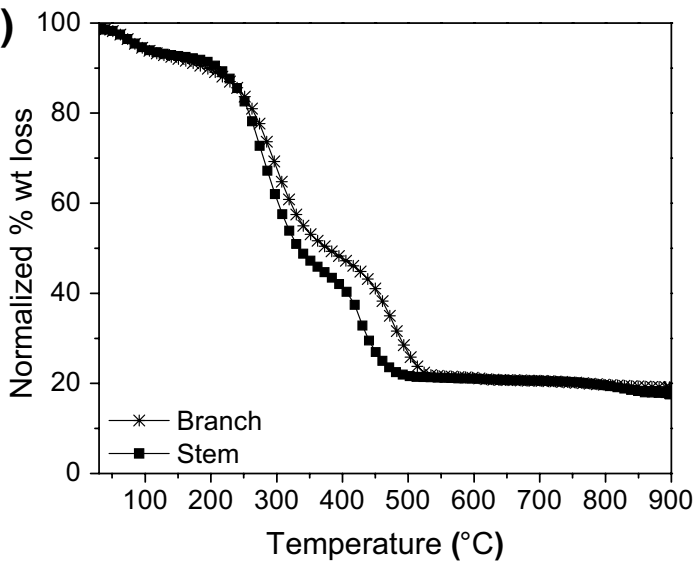

(b)

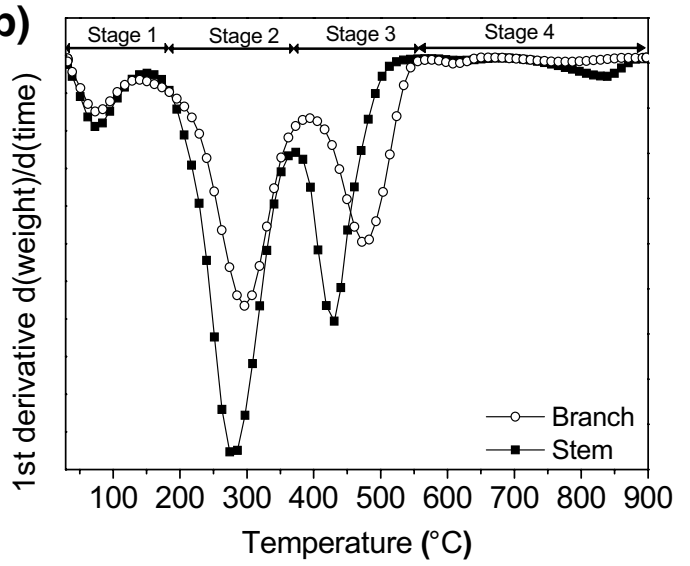

Fig. 6 Thermal decomposition of native Equisetum arvense is shown as a TGA curves and $\mathbf{b}$ 1st derivative curve

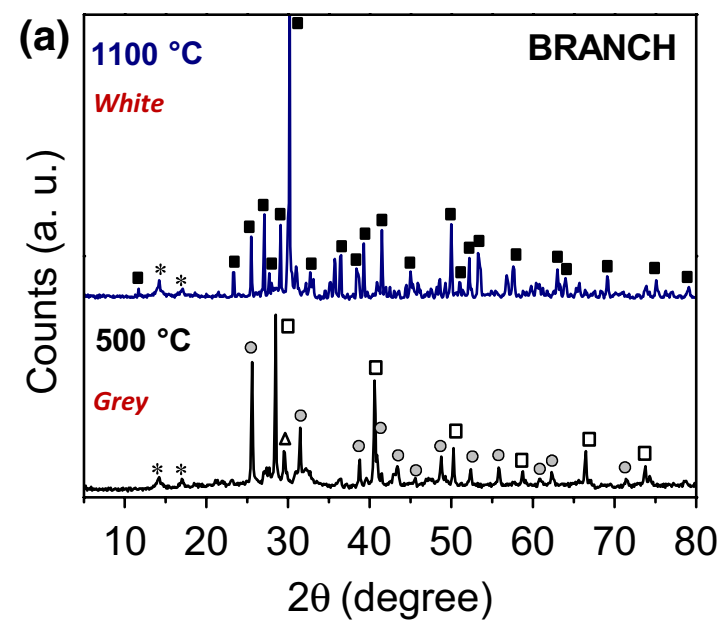

Fig. 7 XRD diffractograms of Equisetum arvense after heat treatment under air for $\mathbf{a}$ branch and $\mathbf{b}$ stem. Crystallographic phases identified were: $\mathrm{KCl}$ (open square); $\mathrm{CaSO}_{4}$ (filled gray circle); $\mathrm{C}-\mathrm{S}-\mathrm{H}$

[46]. The presence of lignin has been reported in vascular plants such as Equisetum arvense and the antiquity of this plant species corresponds with the appearance of lignin digesting enzymes in fungi [47]. Its content is typically less than cellulose [48] as shown in Supplementary Figure 2. Further, due to the complex structure of lignin, thermal stability can vary between types and species of plants [49], and, likewise (as observed in this study), within parts of the same plant. Plants that accumulate higher amounts of biogenic silica tend to present lower concentrations of lignin, as it is suggested that the presence of silica may substitute the mechanical role of lignin [50]. The last stage of weight loss $\left(800-900{ }^{\circ} \mathrm{C}\right)$, was only observed in the stem. A higher amount of silicon (ICP-OES data), as well as, the presence of silanol groups was more apparent in stems than in the branches (ATR data); suggesting that the weight loss, in

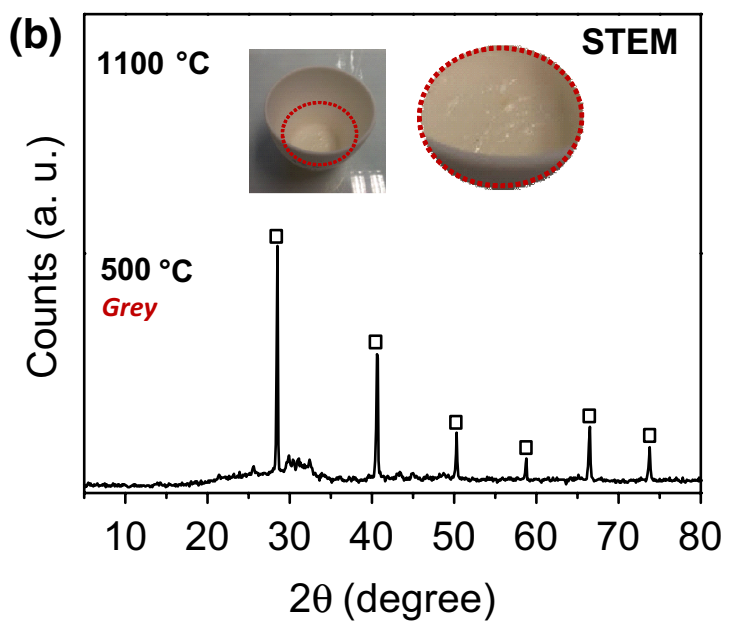

(open triangle) and $\mathrm{CaSiO}_{3}$ (filled square). Peaks arising from the PP holder are labeled with an asterisk. Sample color after treatment is indicated in red

this case, can be associated to dehydroxylation of silanols. Different types of silanol groups can be present in silica: internal, vicinal, isolated and geminal, and, it has been reported that geminal silanols are removed from the surface at temperatures between 800 and $900{ }^{\circ} \mathrm{C}$ [51].

\section{The effect of thermal and/or chemical treatment on composition}

\section{Heat treatment in air}

Samples studied after heat treatment presented different crystalline composition (Fig. 7). Both, stems and branches, heated at $500{ }^{\circ} \mathrm{C}$ showed characteristic XRD diffraction peaks of $\mathrm{KCl}$, corresponding to the cubic structure (JCPDS card No. 41-1476, space group Fm-3 m). Peaks 
Fig. 8 ATR spectra of thermal treated Equisetum arvense for the branch and the stem. No spectrum of the stem sample heated at $1100{ }^{\circ} \mathrm{C}$ is shown due to vitrification of the sample

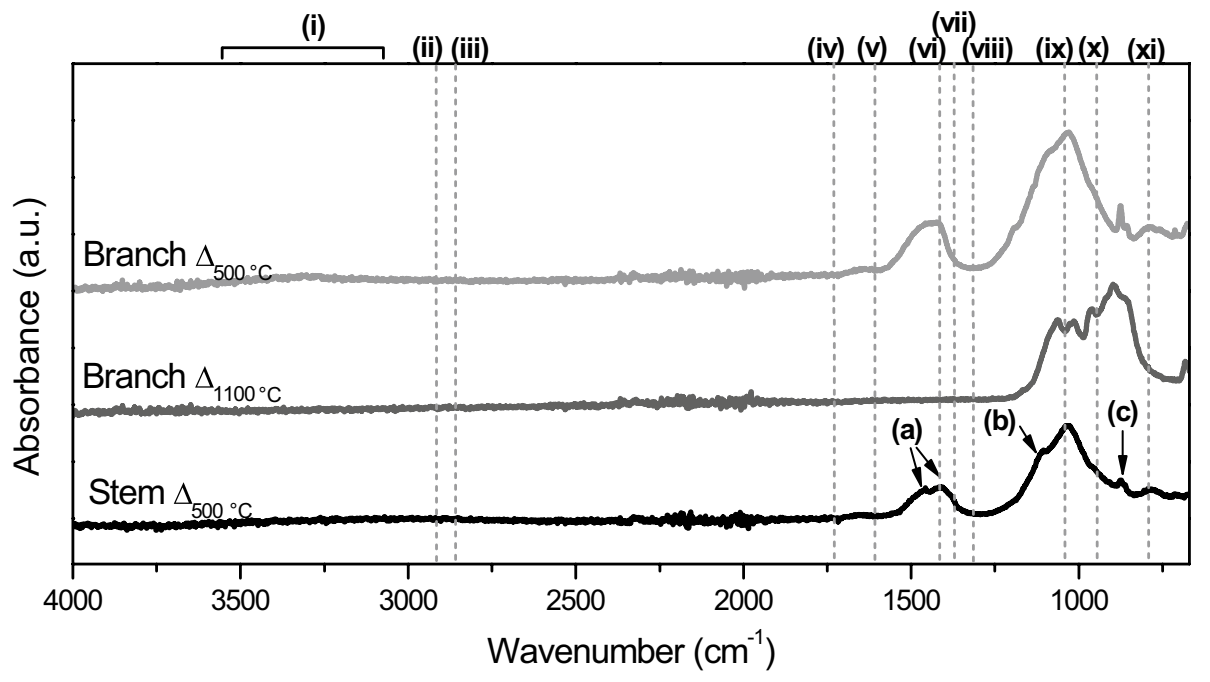

at $2 \theta \sim 28.5^{\circ}, 40.6^{\circ}, 50.3^{\circ}, 58.6^{\circ}, 66.4^{\circ}$ and $73.7^{\circ}$ matched the (200), (220), (222), (400), (420) and (422) planes of $\mathrm{KCl}$, respectively [52]. The presence of $\mathrm{CaSO}_{4}$, with an orthorhombic structure (JCPDS card No. 37-1496, space group Amma) was, however, detected in the branches. After heat treatment, amorphous silica was not detected in the branches, suggesting that the silica present (though detected by ATR analysis of native material) could have been transformed to a crystalline phase, either as crystalline silica or in combination with other elements. The peak at $2 \theta \sim 29.7^{\circ}$ with a $d$-spacing value of $3.0 \AA$ could be associated to (110) planes of calcium silicate hydrate $(\mathrm{C}-\mathrm{S}-\mathrm{H})$ [53-55] and no pure crystalline silica was formed by heating (peaks expected for cristobalite, tridymite and quartz were all absent from XRD diffraction pattern). At higher temperature $\left(1100{ }^{\circ} \mathrm{C}\right)$, the main crystalline phase observed was calcium silicate $\left(\mathrm{CaSiO}_{3}\right)$ corresponding to a wollastonite like structure (JCPDS card No. 43-1460, space group $\mathrm{P}$ ), which corroborated the assignment of the $\mathrm{C}-\mathrm{S}-\mathrm{H}$ peak in the sample heated at lower temperature. In contrast, the stems vitrified into the crucible on thermal treatment. The formation of glass from amorphous silica is typically performed in the presence of feldspar which contains the presence of alkaline fluxing agents (such as $\mathrm{K}, \mathrm{Ca}$ and $\mathrm{Na}$ ) [56], in this case, the presence of $\mathrm{KCl}$, may have favored the reduction of the glass transition temperature $\left(T_{\mathrm{g}}\right)$ for the formation of the glass. The XRD pattern of the vitrified sample containing $\mathrm{Si}, \mathrm{K}$ and $\mathrm{O}$ only $(\mathrm{Si}: \mathrm{K} \sim 3)$ is presented in Supplementary Figure 3. But it was not possible to identify the phases(s) present.

ATR spectra of the samples after heat treatment (Fig. 8) did not show the presence of water after samples were heated at the highest temperature, $1100{ }^{\circ} \mathrm{C}$, and only a small amount for samples heated at the lower temperature (peak i). No presence of alkyl groups (peaks ii, iii, vi, vii and viii) and/or carbonyl groups (peak iv) was detected in any of the samples. Therefore, peak vi was, in this case, no longer attributable to alkyl groups; instead, a double peak in the region of $1420-1515 \mathrm{~cm}^{-1}$ (peak a) probably corresponds to $\mathrm{CO}_{3}{ }^{2-}$ groups in silicate glasses after dissolution of $\mathrm{CO}_{2}$ at high temperatures and pressures relevant to the magma state [57]. These double peaks accompanied by a peak at $\sim 872 \mathrm{~cm}^{-1}$ (peak c) are related to the carbonation of $\mathrm{C}-\mathrm{S}-\mathrm{H}$ when a high $\mathrm{Ca} / \mathrm{Si}$ ratio is present in the sample $[58,59]$. ICP-OES data showed a higher $\mathrm{Ca} / \mathrm{Si}$ ratio in the samples compared with the native material, increasing from $\sim 0.6$ to $\sim 1.1$ in the branches and from $\sim 0.1$ to $\sim 0.3$ in the stems. The symmetric and antisymmetric stretching vibrations of $\mathrm{SiO}_{4}$ in $\mathrm{C}-\mathrm{S}-\mathrm{H}$ (peaks ix and xi, respectively) were observed in the samples heated at $500{ }^{\circ} \mathrm{C}$. The peak at $\sim 1115 \mathrm{~cm}^{-1}$ (peak b) was attributed to sulphate groups as in $\mathrm{CaSO}_{4}$, corroborating the crystalline phase detected by XRD in Fig. 7 a [60]. At higher temperatures $\left(1100{ }^{\circ} \mathrm{C}\right)$, the peaks observed in the region of $800-1100 \mathrm{~cm}^{-1}$ were attributed to the silicate tetrahedral vibration commonly observed for wollastonite [57].

The total $\%$ of weight loss was reduced to $\sim 75 \%$ when the plant material was heated at $500{ }^{\circ} \mathrm{C}$. In the case of branches heated at $1100{ }^{\circ} \mathrm{C}$, less than $1 \%$ of organic material remained in the sample. Four stages of weight loss were observed for TGA analysis of samples that had previously been heated up to $500{ }^{\circ} \mathrm{C}$ (Fig. 9). In the first stage, the release of physisorbed water and/or intercalated water $\left(T<200^{\circ} \mathrm{C}\right)$ was observed. In the second stage $(200$ $550{ }^{\circ} \mathrm{C}$ ), the weight loss observed mainly in the branches could be attributed to the release of $\mathrm{SO}_{x}$ from the crystal phase $\left(\mathrm{CaSO}_{4}\right)$ detected in the sample (XRD data). In the third stage $\left(550-650{ }^{\circ} \mathrm{C}\right)$, combustion of remaining $\mathrm{C}$ in the samples to $\mathrm{CO}_{x}$ was most likely. In stage four, at temperatures between 800 and $900{ }^{\circ} \mathrm{C}$, the loss of hydroxyl groups and recrystallization of Wollastonite $\left(\mathrm{CaSiO}_{3}\right)$ occurred $[61,62]$. 

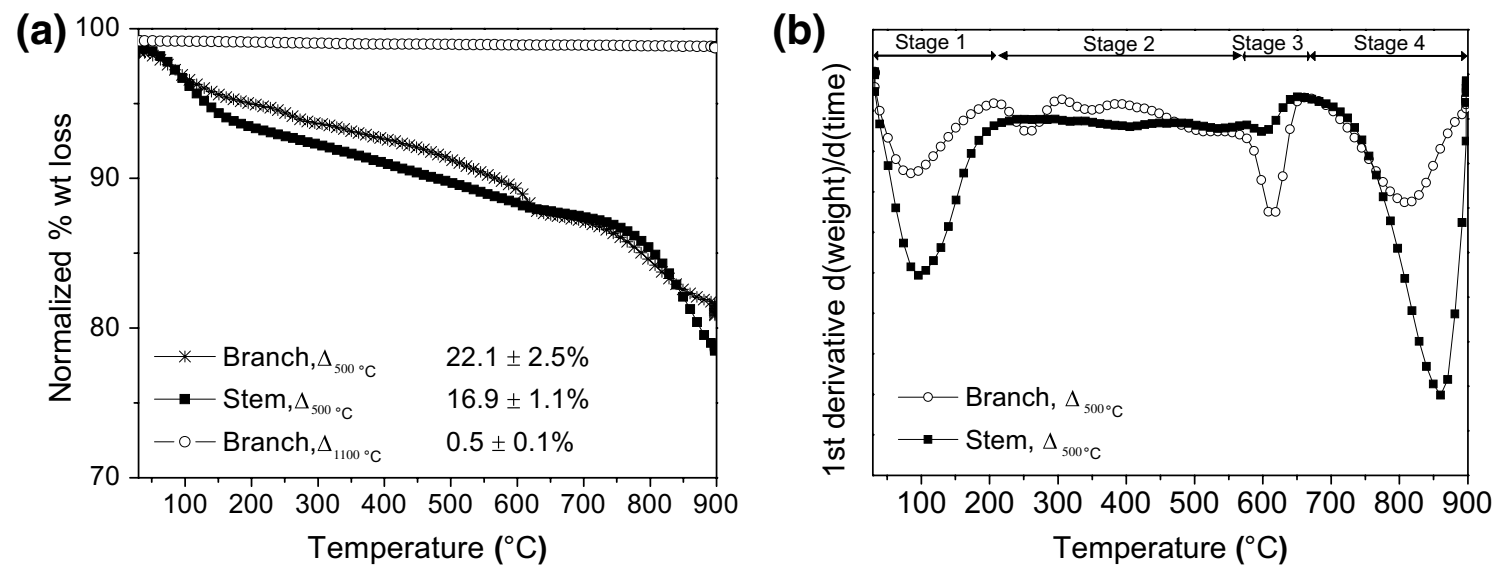

Fig. 9 Thermal decomposition of heat-treated Equisetum arvense is shown as a TGA curves including values of total \% wt loss and, b DTG curve for samples previously heated at $500{ }^{\circ} \mathrm{C}$

Fig. 10 XRD diffractograms of the plant material after acid wash and then heat treatment under $\mathrm{H}_{2} / \mathrm{Ar}$ at $1100{ }^{\circ} \mathrm{C}$ for $5 \mathrm{~h}$ a branch and $\mathbf{b}$ stem. Crystallographic phase identified is amorphous $\mathrm{SiO}_{2}$ (filled black triangle). Peaks arising from the PP holder are labeled with an asterisk. Sample color after treatment is indicated in red
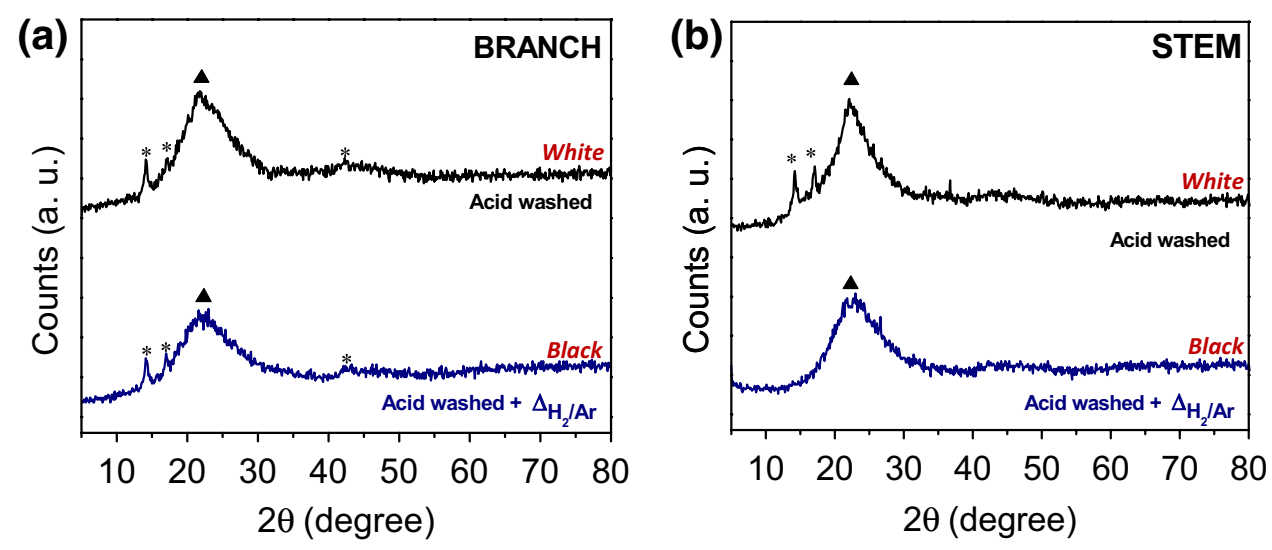

Acid washing and heat treatment under $\mathrm{H}_{2} / \mathrm{Ar}$ on composition

Prior to heat treatment under a reducing atmosphere, plant material was digested with $\mathrm{HNO}_{3}$ and $\mathrm{H}_{2} \mathrm{SO}_{4}$ (4:1) to remove metal ions present in the native material and isolate the biogenic silica. In this study, two batches of sample were studied: (i) complete washing after digestion and (ii) incomplete washing after digestion of the plant material.

i. Complete washing after digestion of the plant material and heat treatment under $\mathrm{H}_{2} / \mathrm{Ar}$

When the plant material was fully digested and carefully washed multiple times with deionized water, the 'only' phase detected in both, branch and stem, was amorphous silica (Fig. 10a). After heat treatment, amorphous silica was still the main phase detected (Fig. 10b) with the difference being that the samples turned black in color due to graphite generated under a reducing atmosphere. Note that, when samples are not carefully rinsed with distilled water prior to the acid treatment, the presence of $\alpha$-quartz can be detected (Supplementary Figure 4). Quartz forms part of the light mineral fraction in soils together with feldspar, and nonferruginous layer silicates [63]. Therefore, contamination from the soil can give rise to confusion as to what is really present in the native plant material. From EDX analysis, all samples contained $>99 \%$ of $\mathrm{Si}$ and $\mathrm{O}$, and other elements constituted $<0.5 \%$ of the sample (without quantification of $\mathrm{C}$ content). These samples contained less than $<1 \%$ of $\mathrm{Ca}$ and $\mathrm{K}$ after digestion and heat treatment and no other elements were detected by EDX and/or ICP-OES analysis. Even so, samples after heat treatment were black in color indicating the presence of $\mathrm{C}$.

Although amorphous silica was the only phase identified by XRD, TGA analysis (Fig. 11), showed still the presence of organic material (less than $25 \%$ ) after acid treatment with weight loss mainly in the region of 150 and $500{ }^{\circ} \mathrm{C}$ (Stage 2). The effectiveness of removal of organic matter varies in digestion period and the excess or otherwise of the acid in relation to the organic material to be removed; therefore, $\%$ of weight loss may vary between sample batches. 

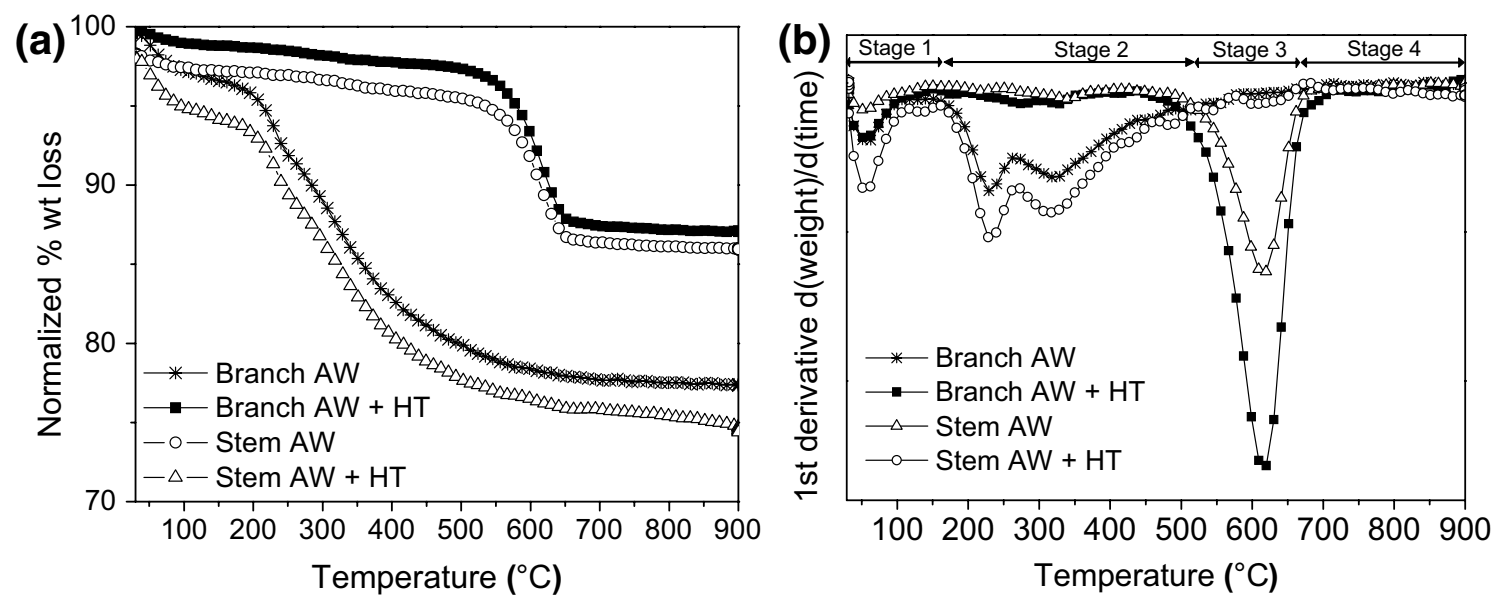

Fig. 11 Thermal decomposition of acid washed (AW) and heat treated (HT) Equisetum arvense plant material is shown as a TGA curves and b DTA curves

Fig. 12 XRD diffractograms of the plant material after incomplete acid digestion and heat treated under $\mathrm{H}_{2} / \mathrm{Ar}$ at $1100{ }^{\circ} \mathrm{C}$ for $5 \mathrm{~h} \mathbf{a}$ branch and $\mathbf{b}$ stem. Crystallographic phases identified are: amorphous $\mathrm{SiO}_{2}$ (filled black triangle); $\mathrm{CaSO}_{4}$ (open circle) and $\mathrm{CaS}$ (filled gray triangle). Sample color after treatment is indicated in red
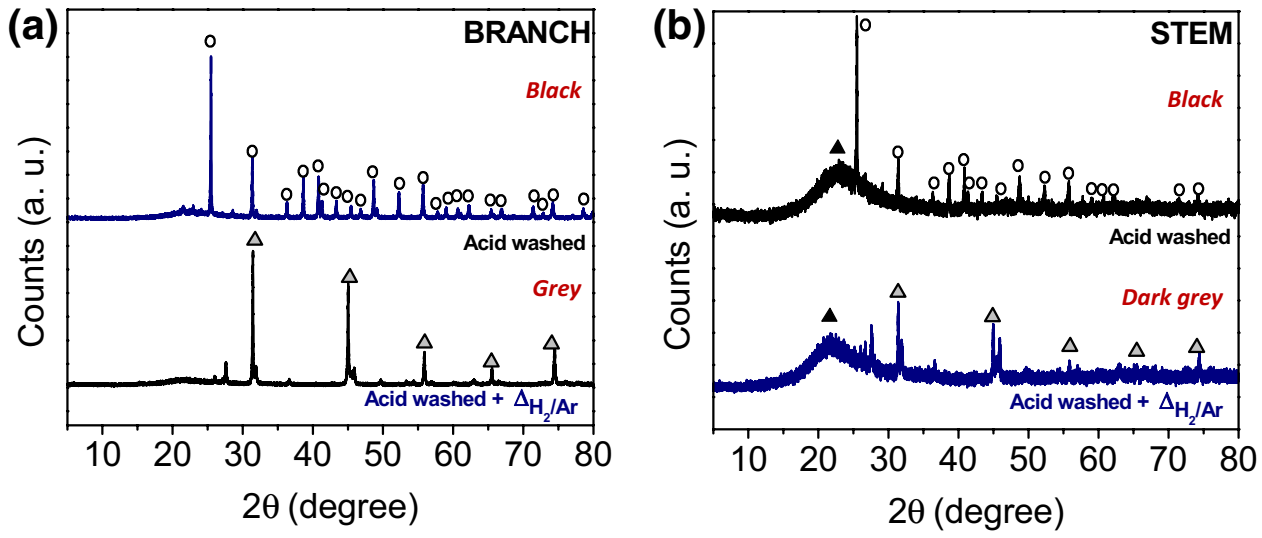

Although heat treatment will eliminate all the remaining organic matter, it is recommended to repeat digestion if values are higher than $25 \%$ as formation of other minerals can be generated by heating in the presence of metal ions (as previously shown). After heat treatment, the weight loss was mainly observed at temperatures between 550 and $650{ }^{\circ} \mathrm{C}$ (Stage 3) due to the combustion of $\mathrm{C}$ in the samples as evidenced by change of color from black to white after TGA analysis. ATR spectra of the samples (Supplementary Figure 5) only showed characteristic peaks of silica (antisymmetric and symmetric $\mathrm{Si}-\mathrm{O}-\mathrm{Si}$ stretching mode and silanol groups) and for only digested samples the presence of water, alkyl groups and silanol groups was still observed (Supplementary Figure 5).

ii. Incomplete washing after digestion of the plant material and heat treatment under $\mathrm{H}_{2} / \mathrm{Ar}$

When the samples (branch or stem) were incompletely washed following acid digestion, calcium sulphate $\left(\mathrm{CaSO}_{4}\right)$ (JCPDS card No. 37-1496) was detected as the main crystalline phase (Fig. 12). Amorphous silica was also detected, being more apparent in the stem sample (Fig. 12b) than in the branch sample (Fig. 12a). Generally, less crystallinity was observed in the stems compared with the branches. Under a reducing atmosphere, peaks from calcium sulphate transformed to a cubic structure attributed to calcium sulphide (CaS) (JCPDS card No. 77-2011, space group Fm-3 m). The presence of $\mathrm{CaSO}_{4}$ in the samples suggested that the plant material was not properly washed after acid treatment. From EDX analysis, the only elements detected were $\mathrm{Si}$ and $\mathrm{O}$ (main peaks) followed by $\mathrm{Ca}$ and S. ICP-OES data showed an increase of $\mathrm{S}$ content in the samples (compared with the native material) from $\sim 1.6$ to $\sim 9.0 \%$ in the branches and from $\sim 0.4$ to $\sim 2.0 \%$ in the stems (up to 6 times more) suggesting that the $\mathrm{CaSO}_{4}$ detected in the samples (without heat treatment) was possibly generated during the acid digestion. ATR spectra of the samples after acid wash and heat treatment (Supplementary Figure 4) showed the characteristic peaks of silica. In this case, digested samples also showed a peak at $\sim 680 \mathrm{~cm}^{-1}$ attributed to $\mathrm{Si}-\mathrm{O}$ rings besides the presence of water, alkyl groups and silanol groups (Supplementary Figure 4). 
Fig. 13 Branches treated with acetone prior to the acid wash and post-heat treatment under $\mathrm{H}_{2} / \mathrm{Ar}$ at $1100{ }^{\circ} \mathrm{C}$ during $5 \mathrm{~h}$ characterized by a XRD of branches treated with acetone prior to the acid wash and postheat treatment under $\mathrm{H}_{2} / \mathrm{Ar}$ at $1100{ }^{\circ} \mathrm{C}$ during $5 \mathrm{~h}$. Crystallographic phases identified are: $\mathrm{CaO}$ (filled downward black triangle); $\alpha$-quartz (open star); and $\mathrm{CaS}$ (filled gray triangle) where peaks arising from the PP holder are labeled with an asterisk, and $\mathbf{b}$ ATR spectrum
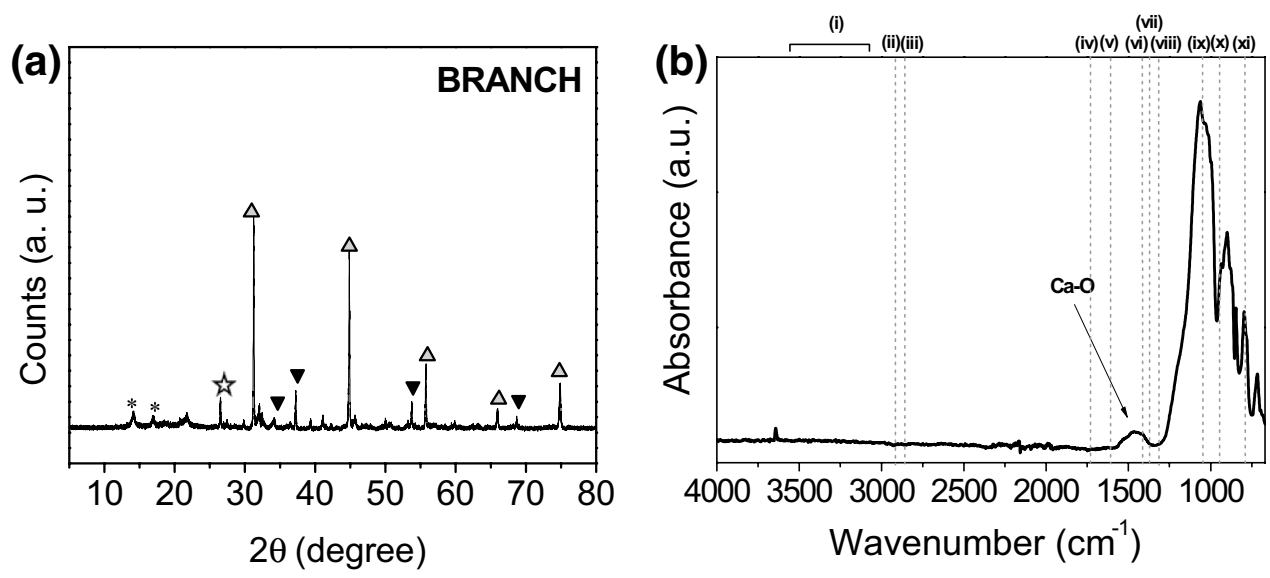

During this set of experiments, branches were also treated with acetone prior to the acid wash and post-heat treatment under $\mathrm{H}_{2} / \mathrm{Ar}$ in order to extract the chlorophyll present in the plant. In this case, samples collected at the end of all treatments were no longer black but yellowish. XRD analysis, showed the presence of $\mathrm{CaS}$ previously observed for the non-acetone treated samples but also calcium oxide $(\mathrm{CaO})$ with cubic structure (JCPDS card No. 70-5490, space group $\mathrm{Fm}-3 \mathrm{~m}$ ) (Fig. 13a). The formation of $\mathrm{CaO}$ can occur by the reaction of $\mathrm{CaS}$ with an excess of unreduced $\mathrm{CaSO}_{4}$ [64]. The presence of $\alpha$-Quartz most probably arose from soil contamination. In ATR spectra (Fig. 13b), a broad peak arising at $\sim 1463 \mathrm{~cm}^{-1}$ was indicative of a $\mathrm{CaO}$ phase in the structure [65]. The peak detected at $\sim 680 \mathrm{~cm}^{-1}$ could be attributed to $\mathrm{Si}-\mathrm{O}$ rings; however, the presence of a peak at $\sim 902 \mathrm{~cm}^{-1}$ and the irregular shape of the peaks, showed similarities with the $\mathrm{CaSiO}_{3}$ (Wollastonite) previously found in the branches heat treated at $1100{ }^{\circ} \mathrm{C}$. If present, this was clearly a minor component of the sample as the mineral was not detected by XRD.

\section{Luminescence behavior}

The samples that showed luminescence, Fig. 1, either contained $\mathrm{CaS}$ generated by the chemical/thermal treatment process or quartz as a result of soil contamination that had not been removed prior to sample treatment and cannot completely be excluded as a possibility. For the latter, luminescence properties have been related to the presence of defects in its crystal lattice [66] which can be caused by the presence of other elements, in this case, by the presence of ions from $\mathrm{CaS}$ and/or $\mathrm{CaO}$. For $\mathrm{CaS}$, a study carried out by $\mathrm{W}$. Lehman showed 31 different possible co-activators of $\mathrm{CaS}$ phosphors (i.e. $\mathrm{Si}, \mathrm{K}, \mathrm{Na}, \mathrm{P}$ or $\mathrm{Cl}$ ) each producing its own emission color. Interestingly, blue-green emission (as in this study) was observed with addition of $\mathrm{CaO}$ to $\mathrm{CaS}$ [67].

\section{Conclusions}

Equisetum arvense contains silica and other elements including $\mathrm{Ca}, \mathrm{K}, \mathrm{S}, \mathrm{Na}, \mathrm{Mg}, \mathrm{Cl}$ and $\mathrm{P}$ with varying distribution patterns across the plant. Silica was essentially detected on the spotted surfaces which generally contained a stomatal shape, whereas the multi-laminate layers showed a higher amount of $\mathrm{K}$ and $\mathrm{Ca}$ as well as lower amounts of $\mathrm{S}, \mathrm{Na}, \mathrm{Mg}, \mathrm{Cl}$ and P. Higher levels of calcium were found in the branches, whereas $\mathrm{K}$ was found at higher levels in the stems. A higher crystallinity was observed in samples obtained from branches compared to the stems, with the latter showing higher silicon (ICP-OES) levels as amorphous silica (XRD). For this plant, solation of 'pure' biogenic silica was only achieved by pre-treatment of samples with concentrated acids. When heat treatment under air was applied to the plant material, crystalline phases other than amorphous silica were isolated due to the presence of metal ions in the plant material such as $\mathrm{Ca}$ and $\mathrm{K}$, producing crystalline phases of these elements with or without combination with silicon. As $\mathrm{K}$ was more likely to be found in the stems, heat treatment gave rise to the formation of $\mathrm{KCl}$, whereas branches, with generally a higher fraction of $\mathrm{Ca}$, formed calcium sulphate and/or calcium silicates (monohydrate or wollastonite). When stems were subjected to a high temperatures $\left(>1000{ }^{\circ} \mathrm{C}\right)$ vitrification of the sample was observed. The presence of $\alpha$-quartz peaks in the samples was shown to arise from soil contamination. When samples were not efficiently washed after digestion, the presence of sulphates could be detected in the heated samples, which subsequently formed sulphides by heat treatment under reducing conditions. Luminescence was observed for a sample which contained $\mathrm{CaS}$ and $\mathrm{CaO}$ or $\alpha$-quartz.

Acknowledgments Funding from AFOSR FA9550-13-1-0040 is gratefully acknowledged by ASR and CCP. 
Open Access This article is distributed under the terms of the Creative Commons Attribution 4.0 International License (http://creativecommons.org/licenses/by/4.0/), which permits unrestricted use, distribution, and reproduction in any medium, provided you give appropriate credit to the original author(s) and the source, provide a link to the Creative Commons license, and indicate if changes were made.

\section{References}

1. Lowenstam HA, Weiner S (1989). On Biomimeralization. Oxford University Press, Oxford

2. Iler RK (1979) The chemistry of silica: solubility, polymerization, colloid and surface properties, and biochemistry. Wiley, New York

3. Page CN (1972) BOJ Bot J Linn Soc 65:359-397

4. Perry C, Fraser M (1991) Philos Trans Royal Soc Lond B Biol Sci 334:149-157

5. Mann S, Perry CC, Williams RJ, Fyfe CA, Gobbi GC, Kennedy GJ (1983) J Chem Soc Chem Commun 4:168-170

6. Perry CC, Mann S, Williams R, Watt F, Grime G, Takacs J (1984) Proc Royal Soc Lond B Biol Sci 222:439-445

7. Chen C, Lewin J (1969) Can J Bot 47:125-131

8. Davis ME (2002) Nature 417:813-821

9. Slowing II, Trewyn BG, Giri S, Lin V (2007) Adv Funct Mater 17:1225-1236

10. Perry CC, Lu Y (1992) J Chem Soc Faraday Trans 88:2915-2921

11. Currie HA, Perry CC (2007) Ann Bot 100:1383-1389

12. Perry CC, Keeling-Tucker $\mathrm{T}$ (2003) Colloid Polym Sci 281:652-664

13. Carnelli AL, Madella M, Theurillat J (2001) Ann Bot $87: 425-434$

14. Leggett GE, Westermann DT (1973) J Agric Food Chem 21:65-69

15. Novozamsky I, Van Eck R, Houba V (1984) Commun Soil Sci Plant Anal 15:205-211

16. Labun P, Grulova D, Salamon I, Šeršeň F (2013) Food Nutr Sci 4:510

17. Reay P, Bennett W (1987) Anal Chim Acta 198:145-152

18. Sterling C (1967) Am J Bot 54:840-844

19. Lanning FC, Ponnaiya BW, Crumpton CF (1958) Plant Physiol 33:339-343

20. Bauer P, Elbaum R, Weiss IM (2011) Plant Sci 180:746-756

21. Anh BTK, Kim DD, Tua TV, Kien NT, Anh DT (2011) J Environ Biol 32:257-262

22. Pant D, Sharma V, Singh P (2015) Toxicol Rep 2:716-720

23. Cheeseman JM, Hanson JB (1979) Plant Physiol 64:842-845

24. Evans HJ, Sorger GJ (1966) Annu Rev Plant Physiol 17:47-76

25. Leigh R (1984) Wyn Jones R N Phytol 97:1-13

26. Holzhüter G, Narayanan K, Gerber T (2003) Anal Bioanal Chem 376:512-517

27. Walker DJ, Leigh RA, Miller AJ (1996) Proc Natl Acad Sci USA 93:10510-10514

28. Hepler PK (2005) Plant Cell 17:2142-2155

29. Dayanandan P, Kaufman P, Franklin C (1983) Am J Bot 70:1079-1084

30. Sangster AG, Hodson MJ, Tubb HJ (2001) Stud Plant Sci 8:85-113

31. Shimizu K, Del Amo Y, Brzezinski MA, Stucky GD, Morse DE (2001) Chem Biol 8:1051-1060

32. Znachor P, Nedoma J (2008) J Phycol 44:518-525

33. Park S, Baker JO, Himmel ME, Parilla PA, Johnson DK (2010) Biotechnol Biofuels 3:1-10
34. Tang S, Baker GA, Ravula S, Jones JE, Zhao H (2012) Green Chem 14:2922-2932

35. Park SK, Kim KD, Kim HT (2002) Colloids Surf Physicochem Eng Aspects 197:7-17

36. Mittal A, Katahira R, Himmel ME, Johnson DK (2011) Biotechnol Biofuels 4:41

37. Ford ENJ, Mendon SK, Thames SF, Rawlins JW (2010) Cellulose 9:18-23

38. Wada M, Chanzy H, Nishiyama Y, Langan P (2004) Macromolecules 37:8548-8555

39. Smith BC (1998) Infrared spectral interpretation: a systematic approach. CRC Press, London

40. Smith AL (1960) Spectrochim Acta 16:87-105

41. Adel AM, El-Wahab ZHA, Ibrahim AA, Al-Shemy MT (2010) Bioresour Technol 101:4446-4455

42. Heredia-Guerrero JA, Benítez JJ, Domínguez E, Bayer IS, Cingolani R, Athanassiou A, Heredia A (2014) Front Plant Sci 5:305

43. Carrillo F, Colom X, Sunol J, Saurina J (2004) Eur Polymer J 40:2229-2234

44. Yang H, Yan R, Chen H, Lee DH, Zheng C (2007) Fuel 86:1781-1788

45. Wiedemann H (1993) Thermochim Acta 229:215-228

46. Lv D, Xu M, Liu X, Zhan Z, Li Z, Yao H (2010) Fuel Process Technol 91:903-909

47. Floudas D, Binder M, Riley R, Barry K, Blanchette RA, Henrissat B, Martinez AT, Otillar R, Spatafora JW, Yadav JS, Aerts A, Benoit I, Boyd A, Carlson A, Copeland A, Coutinho PM, de Vries RP, Ferreira P, Findley K, Foster B, Gaskell J, Glotzer D, Gorecki P, Heitman J, Hesse C, Hori C, Igarashi K, Jurgens JA, Kallen N, Kersten P, Kohler A, Kues U, Kumar TK, Kuo A, LaButti K, Larrondo LF, Lindquist E, Ling A, Lombard V, Lucas S, Lundell T, Martin R, McLaughlin DJ, Morgenstern I, Morin E, Murat C, Nagy LG, Nolan M, Ohm RA, Patyshakuliyeva A, Rokas A, Ruiz-Duenas FJ, Sabat G, Salamov A, Samejima M, Schmutz J, Slot JC, St John F, Stenlid J, Sun H, Sun S, Syed K, Tsang A, Wiebenga A, Young D, Pisabarro A, Eastwood DC, Martin F, Cullen D, Grigoriev IV, Hibbett DS (2012) Science 336:1715-1719

48. Baucher M, Monties B, Montagu MV, Boerjan W (1998) Crit Rev Plant Sci 17:125-197

49. Beall F (1971) Wood Sci Technol 5:159-175

50. Schoelynck J, Bal K, Backx H, Okruszko T, Meire P, Struyf E (2010) N Phytol 186:385-391

51. Zhuravlev L (2000) Colloid Surf A Physicochem Eng Asp 173:1-38

52. Dai F, Zai J, Yi R, Gordin ML, Sohn H, Chen S, Wang D (2014) Nat Commun 5:3605

53. Houston JR, Maxwell RS, Carroll SA (2009) Geochem Trans 10:1-4866-10-1

54. He Y, Lu L, Struble LJ, Rapp JL, Mondal P, Hu S (2014) Mater Struct 47:311-322

55. Shaw S, Clark S, Henderson C (2000) Chem Geol 167:129-140

56. Taylor M, Brown GE (1979) Geochim Cosmochim Acta 43:61-75

57. Kalinkina EV, Kalinkin AM, Forsling W, Makarov VN (2001) Int J Miner Process 61:289-299

58. Delgado AH, Paroli RM, Beaudoin JJ (1996) Appl Spectrosc 50:970-976

59. Beaudoin JJ, Dramé H, Raki L, Alizadeh R (2008) J Mater Res $23: 2$

60. Song Y, Eom H, Jung H, Malek M, Kim H, Geng H, Ro C (2013) Atmos Chem Phys 13:3463-3480

61. Taylor HFW (1953) J Chem Soc 163-171

62. Trindade M, Dias M, Coroado J, Rocha F (2009) Appl Clay Sci 42:345-355

63. Jackson ML, Barak P (2005) Soil chemical analysis: advanced course. UW-Madison Libraries Parallel Press, Wisconsin 
64. Swift W, Panek A, Smith G, Vogel G, Jonke A (1976) Decomposition of calcium sulfate: a review of the literature. Argonne National Lab Report ANL-76-122, USA

65. Atalay S, Adiguzel H, Atalay F (2001) Mater Sci Eng A 304:796-799
66. Preusser F, Chithambo ML, Goette T, Martini M, Ramseyer K, Sendezera EJ, Susino GJ, Wintle AG (2009) Earth Sci Rev 97:184-214

67. Lehmann W (1972) J Lumin 5:87-107 